UDC

\title{
STRATEGY OF OF ECONOMIC EFFICIENCY ENHANCEMENT FOR LAND USE OF AVIATION TRANSPORT
}

I. Novakovska, Doctor of economics, Associate Professor

Email: novmailll@ukr.net

National Aviation University

M. Stetsyuk, PHD in Economics

Email: 19570511@ukr.net

National Aviation University

N. Ischenko, postgraduate student

Email: natalkai@ukr.net

Institute of Agroecology and Environmental Management of NAAS

L. Skrypnyk, postgraduate student

Email: liliia-nahorna@ukr.net

Institute of Agroecology and Environmental Management of NAAS

\begin{abstract}
The place and significance of land resources in the system of aviation transport have been researched. According to the analysis, aviation transport lands in the general structure of lands do not occupy significant positions (II cluster). But, if used effectively, these lands can be a factor in improving the financial performance of airports. It is shown that an important role in land use play economic levers as a set of assets that operate in the economic plane and operate for economic purposes. The possibilities and potential of economic instruments of regulation and characteristics of institutional support for the implementation of economic levers are research. The priorities of economic influence on the possibilities of use and protection of land of aviation transport have been formed. It is shown that it is important to account the interests of
\end{abstract}


stakeholders and the ability of an objective approach to regulation when formulating land use policies.

Keywords: land resources, air transport, economic tools, priorities of impact.

\section{Topicality.}

Air transport plays a viable role in the development of a national transport network. Air transportation is essential upon conditions of the rapid growth of tourism, business, and other branches. It is worth to emphasize that air transport is an integrating factor by its nature, able to generate brand-new activities. This, inter alia, relates to its own services, as well as to auxiliary spheres. Besides, it promotes the development of international communication. This is, in turn, a matter of international relations. Thus, air business is a sophisticated complex with many tasks and priorities.

The nature and structure of air transport stipulate that some units of its infrastructure and info-servicess hall be within the limits of certain land plots, being a physical ground for such activities. Although, while being used according to a customary scheme, such land plots are unable to promote functioning of air transport as a complex at full extent. In this connection, and to improve the basements of infrastructure units' functioning, it is important to elaborate some new approaches to land management, among them - wider use of economic regulation principles.

Meanwhile, the economic aspects of air transport lands' management and protection remain understudied. What is meant here is the possibility to implement some economic levers, i.e. capacities of economic regulation tools, into the land management process.

\section{Analysis of recent research and publications.}

Nowadays, there is a wide scope of scientific works on matters of air transport development, its priorities, and its capacities. These matters have been studied not only by economists, but also by scientists from some adjacent spheres. Alongside this, there are just a few pieces of research on peculiarities of air 
transport lands' management. Important are the works by Dorosh Y.M. (Dorosh,2011) and Galushko V.P. (Galushko, 2006) . They have elaborated basic notions of capacities and specific features of air transport's lands, the essence of functioning and management thereof. In general, one can define a range of researches and works on these two directions, which form the sights and ways to resolve challenging issues. Possible options to use air transport lands and specific features of this process are analyzed in the researches by Bondarchuk N.V. (Bondarchuk, 2009) and Novakovska O.I. (Novakovska, 2017).

The purpose of the research is the is research a complex of economic aspects in air transport lands' management and protection to elaborate some new priorities for the national policy, devoted not only to airports' infrastructure development but also to proper management of land resources in the branch.

\section{Materials and methods of research}

The methodological basis of the research is a set of modern methods of research: the use of system-structural allowed to determine the essence, structure and basis of economic levers of regulation; statistical analysis - to study the status and dynamics of airport development; Comparative - for comparing land distribution of transport complex by clusters; computer was used to analyze the characteristics of aviation land.

Information support is formed at the expense of legal provisions of central and regional bodies of state power, official information of state bodies of power.

\section{Results of the research and their discussion.}

Airports are essential as for economics, as for support to infrastructure. Statistic values of air branch development in 2018 testify its constant growth. According to State Enterprise "UkrAeroRukh", there were 300.9 thousand flights in the reported year, compared to 254 thousand in 2017.

To talk about airports themselves, 20 airports and aerodromes of Ukraine delivered their services to private flights by both domestic and foreign air companies. During the reported period, the number of arrivals and departures of aircrafts reached the amount of 182.2 thousand (Ministry of Infrastructure, 2018). 
Moreover, the scope of air cargo deliveries grew steadily, and reached $120.1 \%$ in 2018, contrasted to the same in January-November, 2017 (Cargo traffic and volume of transportation, 2018).

As for the scope of cargo deliveries, a rapid increase in its values has been observed since 2014. In 2018, it reached its pre-crisis level - 99.2 thousand tons. Although, this value is still able to grow: in 2003, it was equal to 148.4 thousand tons. Statistic demonstrates a strong dependence and correlation between the scopes of cargo deliveries and periods of crisis and stability. Economic reforms in Ukraine and support to the development of its economy shall form positive conditions for growth in volumes of cargo deliveries to continue (Derzhstat of Ukraine, 2018).

It is also positive that foreign companies become more and more interested in air transport development. Apropos, the actual beginning of such companies' activities has already resulted in the extension of a destination network thanks to them. The foreign companies bring competition, thus forcing the domestic air transport to improve and develop itself. In margins of this trend, the brand-new approaches to running air transport business will be implemented gradually (among them those relating to land management).

However, it is important to avoid making any artificial barriers for such air companies, not to occlude certain airports or destinations for them. Such cases already exist and demonstrate significant lobbying forces in the branch. In due course, such phenomena shall have been overcome.

An area of land is quite essential for activities of every airport and every air transport. Important is to study juridical rules on the management of air transport lands, as they create a "window of opportunities" to transform the current principles of land management, as well as to implement new regulations. The main document is the Land Code of Ukraine. It prescribes that "the following belong to air transport lands: lands occupied by airports, separate structures ..., stations ..., reparation plants of civil aviation ..., objects for air transport maintenance" [5]. 
Likewise, according to the Air Code, the "land plots, occupied by buildings, constructions and equipment, as well as land plots, required to ensure an airport's (aerodrome's) activities and indicated on its General plan" are to be ranked among the lands of an airport (aerodrome) [10].

As for the lands of air transport, a share thereof in the general structure of lands is rather low. According to Stategeocadaster, air transport lands occupy 9.5 thousand hectares, $87.4 \%$ of them are built-up. Among all transport means, air transport's areas possess the third place, after lands of motor and railway transport (Fig. 1).

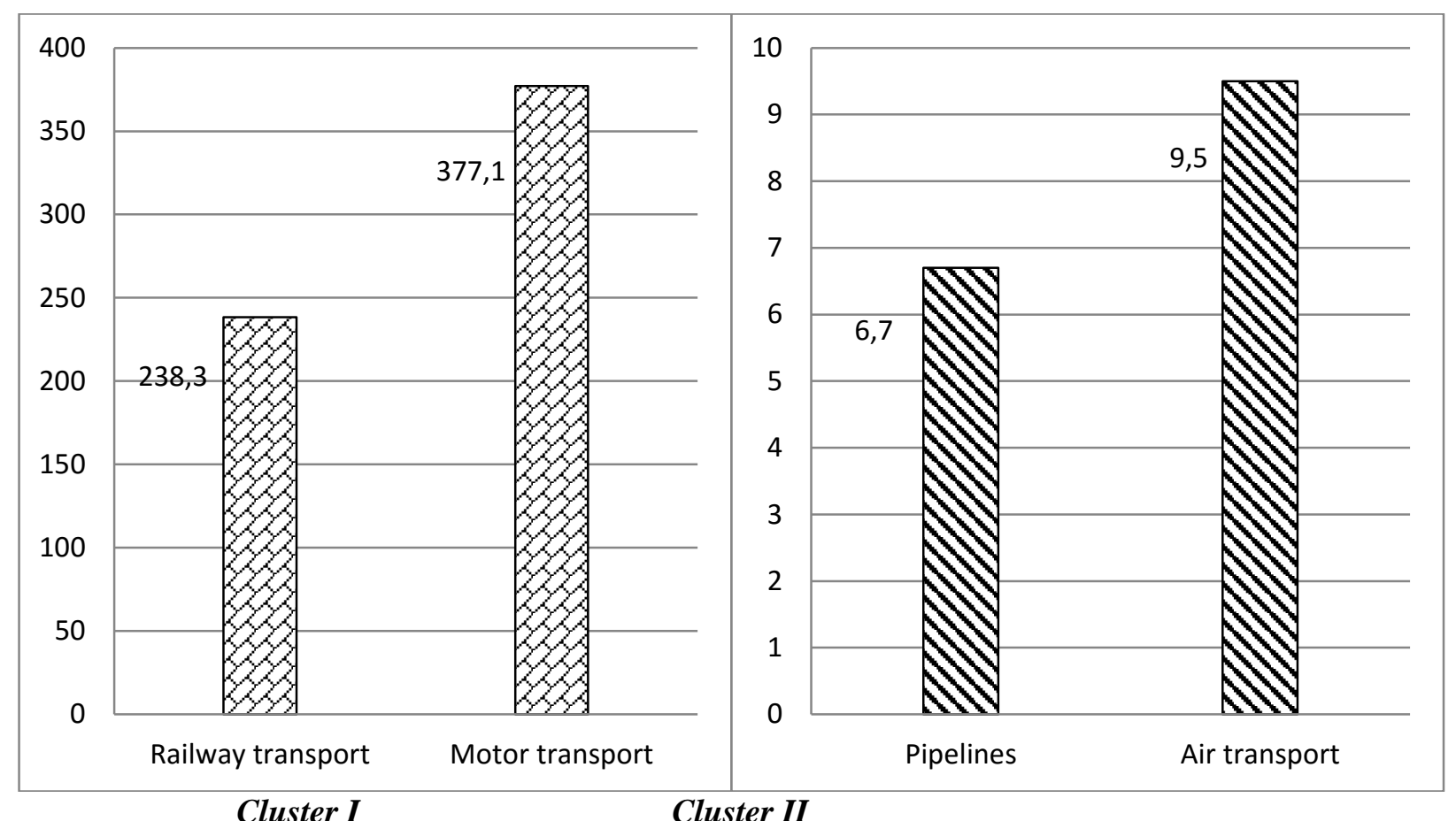

Fig. 1.Structure of the lands of a transport complex, in thousand hectares (Taken from Form6 of the State geocadaster)

Thus, transport branches could be differentiated within the limits of two clusters, according to their shares of lands. The first cluster is formed by railway and motor transport, the second - by pipelines and air transport. Although, it should be noted that such relatively small values of the air transport's areas shall not hinder implementation of new forms and approaches to the use of economic levers. 
To manage and protect air transport lands, it is important to determine the priorities of economic impact. Such impact is achieved with economic levers - a set of means, intended to act in an economic plane and to cope with economic goals. The task of these levers is to form a pinpoint effect, able to generate a pulse, which, in turn, shall govern the object. For instance, rent, investments, and so on could serve as such levers. Upon conditions of market economics, such levers could be rather efficient, because they ensure the connection of a unit of infrastructure with a market environment.

The interest of those, who will promote and support these tools' functioning is essential to study capacities and potentials of economic levers. The mentioned above refers to the position of stakeholders - parties of the interest. They could be the state government or local societies. If the state commences application of the tools, this shall result in changes in a list of activities; if it is triggered by local people, it may have quite specific features. It is an interesting situation if a business subject - an airport itself - is the stakeholder. This case is quite normal, as there are business activities, cash flows, and involvement of other kinds of business. Upon such conditions, airports can act as stakeholders in the implementation and use of economic levers in the sphere of land management.

Rather important is an objective approach to regulation. It stipulates that the mechanism of management influences on the land resources through a set of tools - a "beam of tools" (Fig. 2). In other words, this approach is expedient nowadays, it makes it possible to use all the capacities of regulative tools. For instance, a tool of rent ensures and supports financial flows to budgets; investment potentials stipulate the accumulation of capital contributions. The whole range of regulative tools will ensure the possibility of simultaneous work of several instruments, positive for options of air transport lands' management and protection.

If to compare an objective approach to regulation with a standard one (simultaneous use of the tools), the first-mentioned shall ensure higher performance and value thereof. 


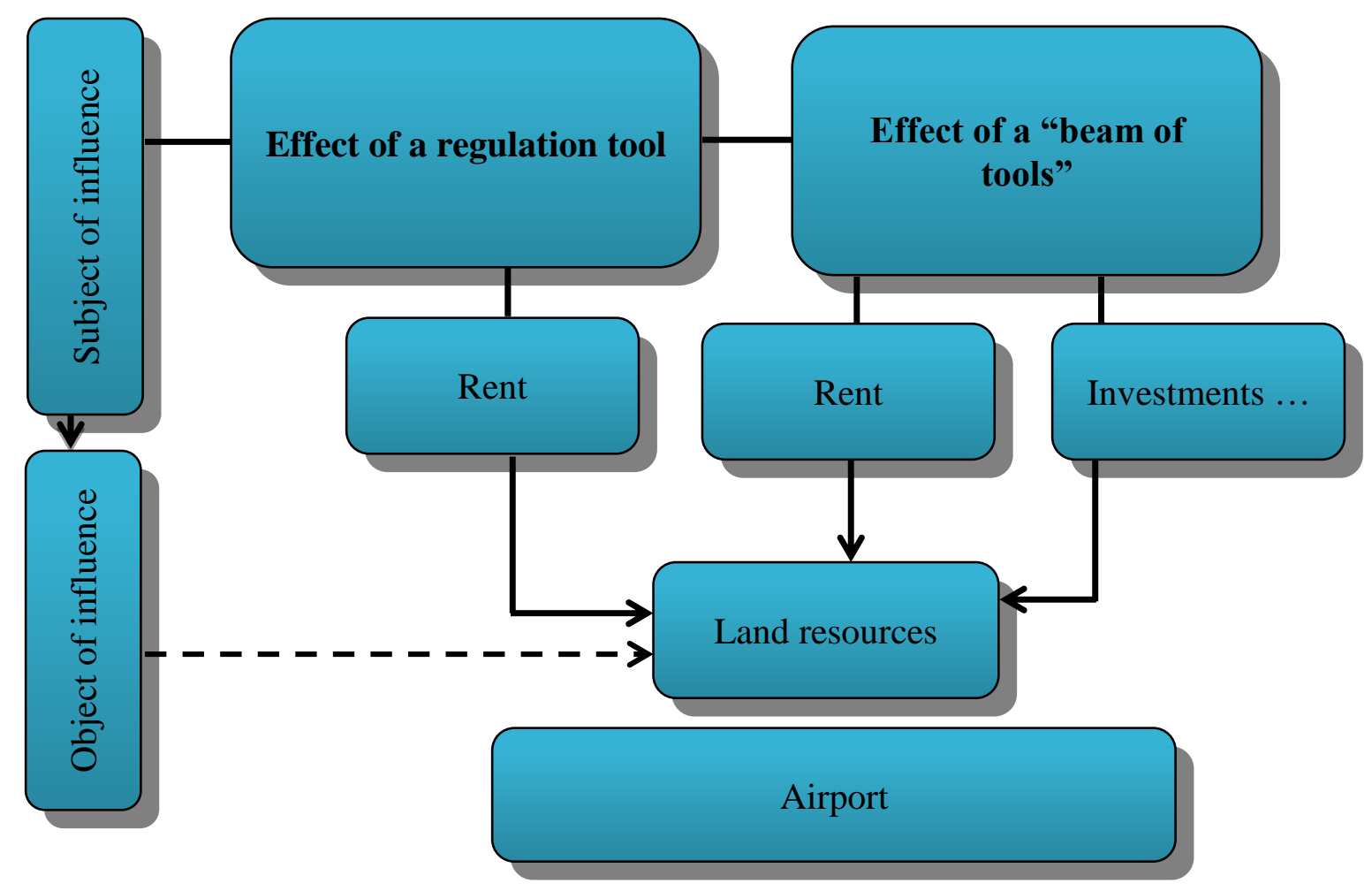

Fig. 2. Probable performance of different regulation tools

The economic levers could be conservative and innovative ones. Conservative levers are ordinary, they have already been used for a quite long period. Among them: investment tools, land rent, tax instruments, etc. These levers ensure the cash flows to budget, however low (within the limits of certain options).

The levers of innovations are very powerful in the sphere of economy, although implementation thereof requires certain prerequisites. Besides, a welldeveloped market and proper market environment are required for these levers to work, to ensure expression and performance thereof.

The best choice is to use both conservative and innovative tools (wellbalanced potentials). However, reality shows that the situation is not a simple one. The existing environment and institutional traps prevent these levers from being implemented and used.

It should be noted that analysis of basic processes in financial and economic regulation retrieved the following to be specific of institutional support: 
First, there is a clear institutional framework, able to ensure the basic functions of the branch. During the whole period of our independence, the processes of environmental management have been developing despite all disorders. They have acquired new features and peculiarities, mostly due to the institutional environment, being formed; consequently, the basic needs were satisfied.

Second, the existing institutional framework is unable to meet up-to-date requirements completely, as in the sphere of environmental management as a whole, as in financial and economic regulation thereof. Besides, it is worth to mention that those requirements are constantly changing. Assessment of the current situation demonstrates that up-to-date parameters of economic development are constantly changing, and institutional support must respond to these changes.

Besides, specific features and peculiarities of air transport do not promote the whole range of the levers, intended for regulation of air transport lands' management and protection.

A possibility to use a group of tools (conservative and innovational) is also predetermined by the specific nature of a certain airport, and by its location. For instance, if an airport is placed next to a large business-center or a transport hub, it is expedient to apply some innovative means (combined with conservative ones). If it is placed in a province - conservative tools are preferable.

Important is implementation of new forms of running a business. It is quite typical that private entities are involved in an airport's activities to ensure investments. This could be achieved through lease, common or sole ownership for a part of an airport. For instance, it relates to opportunities of state-and-private partnership for use of a land plot. Such a partnership could arise in forms of holdings, associations, concessions, clusters. According to the Law "On State and Private Partnership", it is allowed to build a take-off runway for an aerodrome. However, only using a land plot makes it possible (Law of Ukraine "On State and Private partnership", 2010). Within the limits of the measures taken to develop a 
partnership, it is necessary to elaborate prospective plans on probable cooperation. No doubts, the respective options for the airports are restricted to some extent by the specific nature of air transport and by its characteristic, limiting implementation of these kinds of activities.

Within the framework of a partnership between state and private entities, the best possible variant is to attract investments into the development of airports and their infrastructure. Land plots could also have been localized and involved in the concession mechanism. The concession is an important type of cooperation. The essence thereof is that a business entity (concessioner) rents certain objects for an accurately stated period. It purports temporary transfer of title, empowering the concessioner to use such an object to earn income.

Conclusions and perspectives. To speak about ways of possible further researches, it is important to develop basic aspects to transform existing air transport lands' management and protection. It must ensure the proper functioning of the existing approaches and a simultaneous possibility to implement new elements into the currently existing system. The matter of high importance is to elaborate and design the principles on how to implement new approaches and tools into the sphere of land management. Experience of other countries testifies that there are such opportunities, thus they should have been investigated. It is rather expedient also to pay attention on private business initiatives in transformation of the land management system, as private entities are rather more flexible and can cope with any new approaches very fast.

\section{References}

1. Bondarchuk N.V. (2009). Notion and characteristics of air transport lands and their legal regime. State and Law, 46, 431-436 [in Ukrainian]

2. Cargo traffic and volume of transportation from January to November 2018 from

Springer Link https://ukrstat.org/uk/operativ/operativ2018/tr/vp/vp u/vp1118 u.htm. 
3. Dorosh, Y. (2011). Theoretical-methodological basis of land relations development in Ukraine. Kiyv: VIPOL[in Ukrainian]

4. Galushko V.P., Bilyk Y.D., Danylenko A.S. (2006). Land market equation in Ukraine. Ukrain: Urozhaj [in Ukrainian]

5. Informational resource the Ministry of Infrastructure, from SpringerLink https://mtu.gov.ua/content/statistichni-dani-v-galuzi-aviatransportu.html.

6. Novakovska, O. and Skrypnyk L. (2017) The matters of classification and formation of air transport lands. Land management, cadaster, and monitoring, 3, 46-54 [in Ukrainian]

7. The Verkhovna Rada of Ukraine. (2011). Air Code Ukraine: Ukrainian Government Publishing Service.

8. The Verkhovna Rada of Ukraine. (2002). Land code of Ukraine: Ukrainian Government Publishing Service.

9. The Verkhovna Rada of Ukraine. (2010). Law of Ukraine. On State and Private partnership: Ukrainian Government Publishing Service.

10. Volume of shipments by different kinds of transport from SpringerLink https://ukrstat.org/uk/operativ/operativ2018/tr/tr_rik/tr_rik_u/op_vant_vt_u.htm

\section{$* * *$ \\ І. Новаковська, М. Стецюк, Н. Іщенко, Л. Скрипник \\ ЕКОНОМІЧН АСПЕКТИ ВИКОРИСТАННЯ ТА ОХОРОНИ ЗЕМЕЛЬ АВІАЦІЙНОГО ТРАНСПОРТУ}

Анотація. Проведено дослідження місця та значення земельних ресурсів в системі авіаційного транспорту. Як показує проведений аналіз, землі авіаційного транспорту в загальній структурі земель не займають вагомих позицій (Ікластер). Але, за умови ефективного використання, ці землі можуть бути фактором поліпшення фінансових показників діяльності аеропортів. Показано, що в питаннях використання земель важливу роль грають економічні важелі, як сукупність засобів, які функціонують в 
економічній площині та оперують цілями економічного характеру. Проведено аналіз можливостей та потенціалу економічних інструментів регулювання. Досліджено характеристики інституціонального забезпечення впровадження економічних важелів. Сформовано пріоритети економічного впливу щодо можливостей використання та охорони земель авіаційного транспорту. Показано, що при формуванні політики землекористування важливо враховувати інтереси стейкхолдерів та можливості об'єктного підходу до регулювання, який передбачає вплив щодо земельних ресурсів (об’єкту) за допомогою групи інструментів.

Ключові слова: земельні ресурси, авіаційний транспорт, економічні інструменти, пріоритети впливу.

\section{И. Новаковськая, М. Стецюк, Н. Іщенко, Л. Скрипник}

ЭКОНОМИЧЕСКИЕ АСПЕКТЫ ИСПОЛЬЗОВАНИЯ И ОХРАНЫ ЗЕМЕЛЬ АВИАЦИОННОГО ТРАНСПОРТА

Аннотация. Проведено исследование места и значения земельных ресурсов в системе авиационного транспорта. Как показывает анализ, земли авиационного транспорта в общей структуре земель не занимают весомых позиций (Ікластер). При условии эффективного использования эти земли могут выступать фактором улучшения финансовых показателей деятельности аэропортов. Показано, что в вопросах использования земель важную роль играют экономические рычаги как совокупность средств, функционирующих в экономической плоскости и оперирующих целями экономического характера. Проведено анализ возможностей и потенциала экономических инструментов регулирования. Исследованы характеристики институционального базиса использования экономических рычагов. Сформированы приоритеты экономического влияния относительно возможностей использования и охраны земель авиационного транспорта. Показано возможности улучшения политики землепользования при условии 
интеграции интересов стейкхолдеров и возможностей объектного подхода к регулированию.

Ключевые слова: земельные ресурсы, авиационный транспорт, экономические инструменты, приоритеты влияния. 